\title{
Habitat Effects on Condition of Doe Mule Deer in Arid Mixed Woodland-Grassland
}

\author{
Louis C. Bender, ${ }^{1}$ Laurie A. Lomas, ${ }^{2}$ and Tomas Kamienski ${ }^{2}$ \\ Authors are ${ }^{1}$ Research Wildlife Biologist and ${ }^{2}$ Research Assistant, US Geological Survey, New Mexico Cooperative Fish and Wildife Research Unit, \\ PO Box 30003 MSC 4901, Las Cruces, NM 88003.
}

\begin{abstract}
Productivity of mule deer (Odocoileus hemionus Raf.) populations is closely linked to individual nutritional condition. We modeled body fat of individual does as a function of vegetation cover, composition, and water characteristics of their annual, summer, and winter home ranges in north-central New Mexico. We also modeled home range size as a function of the same characteristics. Levels of body fat were most closely and negatively related to the amount of pinyon-juniper in an individual deer's annual home range $\left(F_{1,21}=7.6 ; P=0.012 ; r^{2}=0.26\right)$. Pinyon-juniper types provided little (combined ground cover of preferred forbs and shrubs $=5.7 \%$ ) mule deer forage but were included in home ranges in excess of their availability on the landscape, likely because of security cover attributes. Proportion of grasslands in home ranges was most strongly related to both annual $\left(F_{1,23}=4.9 ; P=0.037 ; r^{2}=0.18\right)$ and summer $\left(F_{2,25}=5.7 ; P=0.009 ; r^{2}=0.31\right)$ home range sizes, and home ranges increased as the grassland component increased, indicating that this habitat type was providing little value to mule deer. Grassland $(0.2 \%$ combined cover of preferred forb and shrub) and montane conifer (3.2\% ground cover of preferred forb and shrub) habitat types similarly lacked preferred mule deer food, and grasslands also lacked cover. Most immediate gains in mule deer habitat in north-central New Mexico may be attained by management of pinyon-juniper communities to increase forage quantity and quality while maintaining cover attributes. Gains can also be realized in grasslands, but here management must establish both cover and forage.
\end{abstract}

\section{Resumen}

La productividad de las poblaciones de venado Bura (Odocoileus hemionus Raf.) esta estrechamente relacionada a la condición nutricional individual. Modelamos la grasa corporal de las hembras en función de la cobertura vegetal, composición y las características del agua de los pastizales anuales de verano e invierno de su territorio en la región norte-centro de New Mexico y también modelamos el tamaño de su territorio en función de las mismas características. Los niveles de grasa corporal estuvieron más estrecha y negativamente relacionados a la cantidad de "Pinyon-juniper" en el territorio anual individual del venado $\left(F_{1,21}=7.6 ; P=0.012 ; r^{2}=0.26\right)$. Los tipos de "Pinyon-juniper" suministraron (combinado con la cobertura de las hierbas y arbustos preferidos $=5.7 \%$ ) poco forraje al venado Bura, pero estuvieron incluidos en el su territorio de pastizal en exceso en relación a su disponibilidad en el paisaje, probablemente por los atributos de seguridad de la cobertura. La proporción de zacatal en el pastizal territorial estuvo más estrechamente correlacionada al tamaño de los pastizales territoriales anual $\left(F_{1,23}=4.9 ; P=0.037 ; r^{2}=0.18\right)$ y de verano $\left(F_{2,25}=5.7 ; P=0.009 ; r_{2}=0.31\right)$, y los territorios se incrementaron conforme el componente zacatal aumentó, indicando que este tipo de hábitat fue de poco valor para el venado Bura. Los tipos de hábitat de zacatal $(0.2 \%$ de cobertura combinando las hierbas y arbustos preferidos) y de coníferas de montaña (3.2\% de cobertura de hierbas y arbustos preferidos) carecieron en forma similar del alimento preferido del venado Bura, y el pastizal también adoleció de cobertura para protección. Las ganancias más inmediatas en el hábitat del venado Bura en la región nortecentro de New Mexico pueden obtenerse manejando las comunidades de "Pinyon-Juniper" para aumentar la cantidad y calidad de forraje, pero manteniendo los atributos de cobertura. Las ganancias también pueden ser obtenidas en los zacatales, pero aquí, el manejo debe enfocarse a establecer tanto cobertura como producción de forraje.

Key Words: body condition, conifer forest, habitat, Odocoileus hemionus, pinyon-juniper

\section{INTRODUCTION}

Mule deer (Odocoileus hemionus Raf.) have been declining throughout their range, including New Mexico, since the late 1950s (Carpenter 1998; Gill 2001). Declines in mule deer populations are both a social and an economic concern because of the importance of mule deer to the public and loss of recreational opportunities (Heffelfinger and Messmer 2003). Many hypotheses have been raised regarding causes of declines,

Correspondence: Louis C. Bender, US Geological Survey, New Mexico Cooperative Fish and Wildlife Research Unit, PO Box 30003 MSC 4901, Las Cruces, NM 88003. Email: Ibender@nmsu.edu

Manuscript received 13 June 2006; manuscript accepted 6 February 2007. including competition with wild and domestic herbivores, predation, overharvesting, habitat loss, fire control, competition with elk (Cervus elaphus L.), and extreme weather (Clements and Young 1997; Gill 2001).

Low deer numbers occur because of low productivity or high mortality (Heffelfinger et al. 2003). Populations cannot grow without adequate production and survival of young, which is driven by body condition of adult females (Verme and Ullrey 1984; Lomas and Bender 2007). Females in poor condition produce fewer recruited young because of delayed sexual maturity, failure to ovulate or conceive, reduced litter size, and the bearing of weak or nonviable fawns (Murphy and Coates 1966; Verme and Ullrey 1984; Lomas and Bender 2007). To accrue sufficient fat for high productivity, does need adequate 
amounts of high-quality forage from their habitat. Therefore, habitat, through its influences on adult female condition, has a direct effect on productivity (Taber 1953; Dietz and Nagy 1976; Lomas and Bender 2007) and survival (Robinette et al. 1952; Anthony 1976; Bender et al. 2007) of mule deer.

Because nutritional condition is fundamental to deer health and productivity (Verme and Ullrey 1984; Wakeling and Bender 2003; Lomas and Bender 2007), understanding which habitat types or features best provide for deer nutrition is fundamental to developing successful habitat management strategies (Clements and Young 1997). Further, documenting habitat use patterns and quantifying habitat characteristics of deer ranges is necessary to understand what habitat attributes are important to mule deer locally, which is prerequisite to restoring local populations (Clements and Young 1997; Carpenter 1998). Thus, our goal was to determine which characteristics of mule deer home ranges were related to nutritional condition of individual deer. Our objectives were to 1) identify home ranges of adult doe mule deer, 2) relate vegetative and other characteristics of home ranges to doe condition, and 3) demonstrate deer distribution patterns with respect to habitat cover types and other characteristics of deer ranges.

\section{METHODS}

\section{Study Area}

Our study area encompassed approximately 486000 ha in Colfax County (approximately lat $36^{\circ} 44^{\prime} \mathrm{N}$, long $104^{\circ} 30^{\prime} \mathrm{W}$ ), north-central New Mexico (Fig. 1). Vegetation types were extremely varied in the area and ranged from mesic mixed spruce (Picea spp.)-true fir (Abies spp.)-Douglas fir (Pseudotsuga menziesii [Mirb] Franco) at higher elevations to xeric grasslands at lower elevations. Ponderosa pine (Pinus ponderosa Dougl. ex Laws) and pinyon-juniper were the predominant forest types present in the site, with varied degrees of understory development due to past management practices. Short grassland, primarily of grama (Bouteloua spp.) grasses, was the most common vegetation type in the study area. Livestock production and commercial hunting were the dominant land uses on private ranches making up the majority of the study area.

Climate in the area was significantly influenced by elevation and aspect. High and low mean temperatures were $-8^{\circ} \mathrm{C}$ in January and $28^{\circ} \mathrm{C}$ in July at Raton, New Mexico. Mean annual precipitation averaged $440 \mathrm{~mm}$, with $62 \%$ falling during MayAugust. Topography ranged from the mountainous Sangre de Cristo range in the northern and western sections to folded mountains, breaks, and rolling low hills to the south and east. Elevations range from $3884 \mathrm{~m}$ at Big Costilla Peak to $1848 \mathrm{~m}$ along the Cimarron River. The area is drained by 3 major watersheds; the Canadian, Vermejo, and Cimarron Rivers, the latter 2 being tributaries of the Canadian.

Most of the land was privately owned. Ranches in the study area included the National Rifle Association Whittington Center, CS Ranch, Chase Ranch, Express Ranch, Moore Ranch, Philmont Scout Ranch, T.O. Ranch, and Vermejo Park LLC. Smaller parcels of public ownership are also in the study area and include portions of the Carson National Forest, the

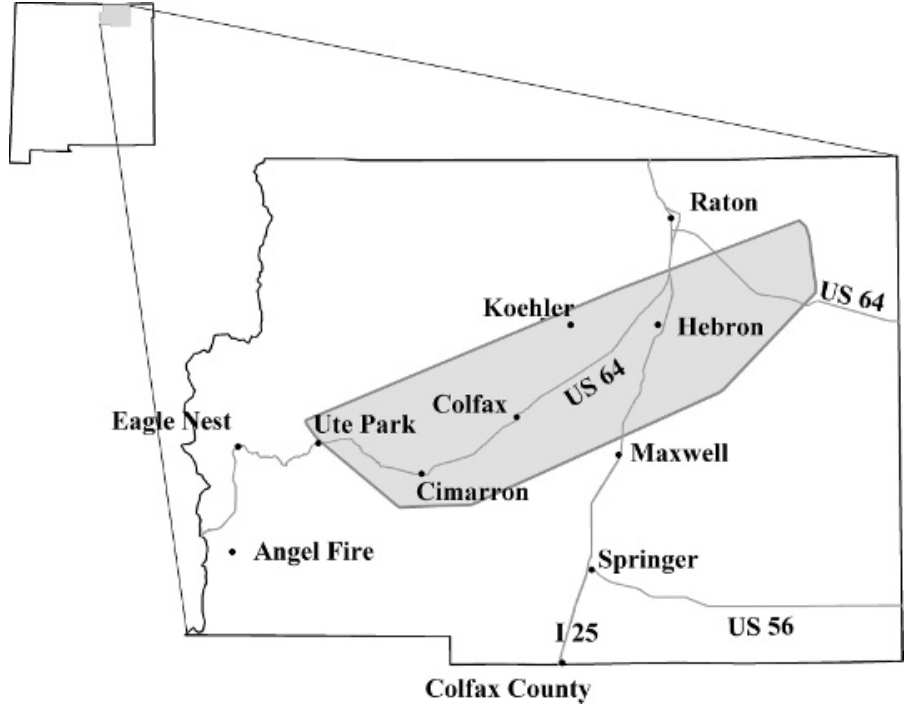

Figure 1. Location of mule deer study area, north-central New Mexico.

Maxwell National Wildlife Refuge, and scattered pieces of state ownership.

\section{Capture and Radiotelemetry}

We initially captured and radio-collared 40 adult female mule deer in December 2001 and captured/recaptured and assessed for condition 21 and 16 deer, respectively, December 2002 and 2003. We captured deer by aerial net gunning or darting from a Hughes 500, Schweitzer 300, or Bell JetRanger 206B helicopter using carfentanil citrate and xylazine hydrochloride. We darted some deer $(<10)$ from vehicles using the same immobilants. We treated deer with antibiotics, vitamin E/ selenium, vitamin B, and an 8-way Clostridium bactrain. Following processing, we antagonized the immobilants with naltrexone and tolazoline. All deer capture and handling procedures were in accordance with New Mexico State University Institutional Animal Care and Use Committee permit 2001-22.

We located radio-collared deer from the ground throughout their daily activity period, a minimum of 2 times per month, with some seasonal emphasis (June-August fawning period), December 2001-2003. We determined the location of each deer by walking in and visually locating the deer, which allowed accurate locations of deer without the need for calculating error polygons.

\section{Doe Nutritional Condition}

We determined percent ingesta-free body fat (IFBF) of does at capture in late November to early December 2002 and 2003 (the approximate peak of condition based on plant phenology in north-central New Mexico) using either subcutaneous rump fat depth measured by an ultrasonograph (Stephenson et al. 2002) or a body condition score (rBCS) modified from Cook (2000) by decreasing all evaluation criteria by one-half based on metabolic size of mule deer versus elk (C. elaphus). Percent IFBF was estimated using IFBF $=5.68+5.93 \times \mathrm{X}$, where $\mathrm{X}$ $=$ subcutaneous rump fat depth (Stephenson et al. 2002). Because this equation can predict body fat down to only $5.7 \%$ (the point where no subcutaneous rump fat is present), we 
Table 1. Preferred grass, sedge, forb, and shrub species in mule deer diets in north-central New Mexico.

\begin{tabular}{|c|c|c|}
\hline Grasses and sedges & Forbs & Shrubs \\
\hline \multirow[t]{2}{*}{ Smooth brome (Bromus inermis Leyss.) } & Alfalfa (Medicago sativa L.) & Mountain mahogany (Cercocarpus montanus Raf.) \\
\hline & Globemallow (Sphaeralcea coccinea & \\
\hline Kentucky bluegrass (Poa pratensis L.) & [Pursh] Rybd.) & Bitterbrush (Purshia tridentata [Pursh] DC.) \\
\hline \multicolumn{3}{|l|}{ Blue grama (Bouteloua gracilis [H. B. K.] Lag. } \\
\hline Ex Steud.) & Burclover (Medicago polymorpha L.) & Fourwing saltbush (Atriplex canescens [Pursh] Nutt.) \\
\hline Side oats grama (Bouteloua curtipendula [Michx.] Torr.) & Purple prairieclover (Dalea purpurea Vent.) & Skunkbush sumac (Rhus aromatica Ait) \\
\hline Timothy (Phleum pratense L.) & Kochia (Kochia americana S. Wats.) & Deerbrush (Ceanothus integerrimus H. \& A.) \\
\hline \multicolumn{3}{|l|}{ Little bluestem (Schizachyrium scoparium [Michx.] } \\
\hline Nash) & Yellow sweetclover (Melilotus officinalis L.) & Gambel's oak (Quercus gambelii Nutt.) \\
\hline Switchgrass (Panicum virgatum L.) & & Sandbar willow (Salix exigua Nutt.) \\
\hline Bush muhly (Muhlenbergia porteri Scribn. ex Beal) & & Aspen (Populus tremuloides Michx) \\
\hline Black grama (Bouteloua eriopoda [Torr.] Torr.) & & Wood's rose (Rosa woodsii Lindl.) \\
\hline \multirow[t]{4}{*}{ Threadleaf sedge (Carex filifolia Nutt.) } & & Wax currant (Ribes cereum Dougl.) \\
\hline & & Winterfat (Ceratoides lanata [Pursh] J. T. Howell) \\
\hline & & Apache plume (Fallugia paradoxa [D. Don] Endl.) \\
\hline & & Big sagebrush (Artemisia tridentata Nutt.) \\
\hline
\end{tabular}

regressed body fat levels of Rocky Mountain mule deer captured in north-central and east-central New Mexico as determined by the previous equation as a function of rBCS to develop a predictive model to predict body fat using rBCS alone (L. Bender, US Geological Survey, unpublished data). This equation, $\mathrm{IFBF}=3.444 \times \mathrm{rBCS}-0.746\left(r^{2}=0.83 ; n=27\right)$, allowed determination of levels of body fat below levels where subcutaneous fat is fully catabolized.

We correlated IFBF with characteristics of annual and seasonal home ranges (including proportion of home range in each vegetation type, annual proportion of locations in each vegetation type, and annual cover of preferred mule deer forages by class; Table 1) using Pearson correlations (Zar 1996) to identify variables related to accrual of IFBF in deer. Finally, we modeled IFBF as a function of these same home range habitat characteristics using stepwise multiple regression (Zar 1996) to identify which variables were most strongly related to accretion of IFBF in individual deer. For these analyses, we included only deer for which we had annual home range data for the year (mid-December-late November) immediately prior to condition assessment in late November or early December.

\section{Deer Distribution and Home Ranges}

We recorded locations of does on a handheld GPS unit and plotted locations in ArcGIS 9.0 geographic information system (Environmental Systems Research Institute, Redfield, CA). We compared annual and seasonal (summer = April-November; winter $=$ December-March) distributions of deer using multiresponse permutation procedures (Slauson et al. 1991) and calculated annual and seasonal home ranges in ArcGIS using 95\% adaptive kernels (AK; Worton 1995). We compared seasonal home ranges to test for migratory status; deer with spatially distinct seasonal ranges were considered migratory. We also computed a $100 \%$ minimum convex polygon (MCP) home range from all locations of all deer combined to define the study area considered available to deer (McClean et al. 1998).

\section{Landscape and Seasonal Distribution}

We delineated habitat types from US Geological Survey's Regional GAP Analysis (ReGAP) land cover classification coverage. We reclassified the original 57 habitat types into 8 habitat types that reflected the general composition of communities in the study area: barren, developed, open water, short-grass prairie, shrub, pinyon-juniper, riparian, and montane conifer. We then used these 8 cover types in our analyses of deer habitat use.

We used the combined 100\% MCP home range described previously to define the study area in terms of habitat types available to deer. We compared the proportion of habitat types within each annual and seasonal home range with the proportion available in the study area. We took the resultant difference by habitat types for each deer and randomly selected with replacement (bootstrapped; Efron and Tibshirani 1993) $N=10000$ combinations of difference values. We then averaged each bootstrap replicate and used the $N=10000$ mean difference values to create a frequency distribution of differences. We ranked the frequency distribution and excluded the extreme 500 values from each tail to develop 90\% bootstrap confidence intervals for the mean difference for each habitat type. If the CI included 0 , then deer were distributed randomly with respect to that habitat type.

We also analyzed distribution of deer seasonally by dividing the number of seasonal locations in a particular habitat type by the total number of locations. We compared seasonal distribution with percent availability from the habitat type composition of the annual home range for each deer individually. We developed bootstrap CIs around the mean difference for each habitat type as described previously. We calculated selection ratios (percent use/percent available) for both home range composition and seasonal use.

We used Pearson correlations (Zar 1996) to explore relations between size of annual and seasonal home ranges and characteristics of home ranges (proportions of habitat types and cover of preferred forages by class [grass, forb, shrub]; see the following discussion). We then used stepwise multiple 
regression (Zar 1996) to model home range size as a function of these same characteristics.

For all home range and habitat use analyses, we used all deer regardless of whether we had end-of-year condition for each individual. All analyses were conducted at the $\alpha=0.10$ level. Where necessary, we partitioned the overall experiment-wise error rate $\left(\alpha_{\exp }=0.10\right)$ into a comparison-wise error rate $\left(\alpha_{\text {com }}\right)$ using $\alpha_{\text {com }}=\left[1-\left(1-\alpha_{\text {exp }}\right)^{1 / k}\right]$, where $\mathrm{k}=$ number of paired comparisons. We then used $\alpha_{\text {com }}$ as our level of significance for tests.

\section{Vegetation Surveys}

We used the US Geological Survey's Southwest ReGAP vegetation classifications to identify the 3 predominant cover types in our study area; short-grass prairie (54\%), pinyonjuniper $(16 \%)$, and montane conifer forest $(26 \%)$. We determined proportions of each type on the study site by overlaying the $100 \%$ MCP combined home range on the vegetation base map.

We established 45 randomly placed permanent transect points, 15 per each major cover type, August 2002 and 2003. Each point consisted of a central point from which 4, 100-m transects radiated out in each cardinal direction. Vegetation measures collected along each transect included percent ground cover, densities of woody stems $<10.2-\mathrm{cm}$ diameter breast height (dbh), densities of woody stems $>10.2-\mathrm{cm} \mathrm{dbh}$, and percent overstory canopy cover. We also established 3 random transects per home range for each deer without stratification by vegetation type and recorded the same vegetation characteristics, 2002 and 2003.

We determined percent ground cover by class (grass, forb, shrub, and other, where other = bare ground, rock, litter, or succulent) and species by recording ground cover by species at each 10 -m point along each radial transect $(n=10 /$ transect, $40 /$ plot). Woody densities were determined using the point-center quarter method (Wyoming Game and Fish 1982), with center points established every $25 \mathrm{~m}$ along the radial transects (4/ transect, 16/plot). In addition, canopy coverage by species was determined at each $25-\mathrm{m}$ point using a spherical densiometer.

We compared ground cover by class between years and among cover types using Kruskal-Wallis analyses of variance (H; Zar 1996). We compared densities of shrubs and overstory trees and overstory canopy coverage between years and between vegetation cover types using Mann-Whitney $U$ tests (Zar 1996). We also performed the same analyses for only key mule deer forage species. We identified key forage species from literature reviews, consultation with local managers, and analyses of rumen contents from natural mortalities and hunter killed deer $(n=31$; L. Bender, US Geological Survey, unpublished data) (Table 1). We also compared abundance of preferred mule deer forages between home ranges and the landscape in general inclusive of vegetation type as described previously.

\section{RESULTS}

\section{Health and Condition}

High mortality of mule deer does (Bender et al. 2007) during our study limited sample size to 23 for modeling of IFBF- habitat characteristics because only 23 does combined in 2002 and 2003 had both annual IFBF estimates and complete annual and seasonal home ranges. Also, because annual home range distributions were similar in 2002 and 2003 (see the following discussion), we pooled locations over years to more precisely define home ranges for IFBF modeling.

Levels of IFBF that does were able to accrue ranged from $5.2 \%$ to $12.2 \%$. Levels of IFBF in deer were negatively related to the proportions of pinyon-juniper in annual $(r=-0.513$; $P=0.012)$, summer $(r=-0.479 ; P=0.021)$, and winter $(r=-0.442 ; P=0.035)$ home ranges. The best predictor of IFBF was the amount of pinyon-juniper in annual home ranges $\left(F_{1,21}=7.6 ; P=0.012\right)$, which was negatively related to IFBF ( $\beta=-0.061)$ and accounted for $26 \%$ of the variance in levels of IFBF does were able to accrue.

\section{Distribution and Home Ranges}

Because of high mortality among study deer (Bender et al. 2007), we were able to adequately define (minimal number of locations for seasonal and annual home ranges $=10$ and 25, respectively, based on plots of home range size as a function of number of locations) complete annual home ranges for 25 deer. Sample sizes used to define annual home range sizes ranged from 25 to 41 for annual and 10 to 26 for seasonal home ranges. Geographic locations of deer home ranges did not vary annually $(P \geq 0.101)$ except in 4 cases $(P \leq 0.005)$ in which migratory deer remained in their summer home range through the winter in 1 year. Thus, we pooled locations among years within a deer to define home ranges. Size of AK home ranges averaged $12.4 \quad(\mathrm{SD}=10.4), 11.2 \quad(\mathrm{SD}=8.8)$, and 14.3 $(S D=20.8) \mathrm{km}^{2}$ for annual, summer, and winter, respectively, for nonmigratory deer. Migratory deer had larger home ranges: $255.4(\mathrm{SD}=90.4), 362.9 \quad(\mathrm{SD}=248.2)$, and $92.7 \quad(\mathrm{SD}=$ 193.4) $\mathrm{km}^{2}$ for annual, summer, and winter, respectively.

Composition of mule deer home ranges differed from the composition of the study area (Table 2). Annual, summer, and winter home ranges each include more pinyon-juniper and less shrub and grassland types than the landscape. Additionally, both annual and summer home ranges contained less free water than did the landscape (Table 2).

Seasonally, mule deer were located in shrub (selection ratio $=21.3$ ) and pinyon-juniper (selection ratio $=1.1$ ) habitat types more than their availability in summer, and were also located in shrub communities (selection ratio $=15.1$ ) more than its availability in winter (Table 3). Mule deer were located in montane conifer (selection ratio $=0.6$ ) and short-grass prairie (selection ratio $=0.9$ ) less than their availability in summer and barren (selection ratio $=0.7$ ) and free water (selection ratio $=0.3$ ) habitat types less than availability in winter.

Modeling of home range size indicated that size of annual home ranges was positively related to the amount of grassland in both annual $(r=0.420 ; P=0.037)$ and summer $(r=$ 0.435; $P=0.030$ ) home ranges and the proportion of deer locations in grasslands $(r=0.419 ; P=0.037)$. The best predictive model of annual home range size included only the proportion of grassland in the summer home range $\left(F_{1,21}=4.9 ; P=0.037\right)$, which was positively related to annual home range size and accounted for $19 \%$ of the variance in size of annual home ranges. 
Table 2. Mean difference between composition of mule deer annual and seasonal home ranges and the composition of the landscape for cover types present in north-central New Mexico. Proportions shown in bold differ from composition of the landscape, with the direction of difference noted by the associate sign.

\begin{tabular}{|c|c|c|c|c|}
\hline \multirow[b]{2}{*}{ Habitat type } & \multirow[b]{2}{*}{ Landscape } & \multicolumn{3}{|c|}{ Home range composition } \\
\hline & & Annual & Summer & Winter \\
\hline Barren & 0.40 & +0.24 & +0.21 & +0.28 \\
\hline Montane & 26.3 & -4.68 & -3.34 & -4.32 \\
\hline Pinyon/juniper & 15.9 & +13.03 & +12.40 & +15.89 \\
\hline Shrub & 0.7 & -0.18 & -0.19 & -0.31 \\
\hline Grass & 54.0 & -11.73 & -12.38 & -13.22 \\
\hline Developed & 2.1 & +2.69 & +2.72 & -1.21 \\
\hline Riparian & 0.3 & +0.76 & +0.77 & +1.10 \\
\hline Free water & 0.3 & -0.15 & -0.18 & +0.08 \\
\hline
\end{tabular}

Similarly, size of summer home ranges was related to the proportion of grasslands in the summer home range $(r=0.463 ; P=0.020)$, the proportion of grassland in the annual home range $(r=0.441 ; P=0.028)$, the amount of preferred grass forage in the annual home range $(r=0.377$; $P=0.070$ ), and the proportion of deer locations in grasslands during the summer $(r=0.524 ; P=0.007)$. The best predictive model of summer home range size included the proportion of the summer and winter home range in grasslands $\left(F_{2,25}=5.7\right.$; $P=0.009$ ), which indicated that home range size increased as the proportion of grassland in the home range increased and accounted for $31 \%$ of the variance in the size of summer home ranges. Size of winter home ranges was not related to any measured characteristic.

\section{Abundance of Suitable Forage}

Total grass, forb, and shrub cover of all species inclusive or of preferred mule deer forage only did not differ between years $(P \geq 0.126)$ and so we pooled data over years for subsequent analysis. Similarly, grass, forb, and shrub cover did not differ between deer home ranges when $>1$ annual home range was defined for a deer or between years among deer $(P \geq 0.199)$ so data were also pooled over years for all subsequent comparisons.

Landscape Composition. The predominant habitat types differed in mean ground cover of grasses $\left(H_{2}=29.3\right.$; $P<0.0001)$ but not forbs $\left(H_{2}=2.0 ; P=0.362\right)$ or shrubs
$\left(H_{2}=2.7 ; P=0.257\right)$ (Table 4). Montane conifer stands had both more trees (203 vs. $66 \cdot \mathrm{ha}^{-1} ; U=-3.8 ; P=0.002$ ) and shrubs (11 174 vs. $3292 \cdot$ ha $^{-1} ; U=-1.8 ; P=0.070$ ) than did pinyon-juniper stands, although both types were highly variable (Table 4). Total canopy coverage was also greater $(U=-2.7 ; P=0.008)$ in montane conifer than pinyonjuniper $(59.8 \%$ vs. $24.7 \%)$.

Little of the understory present in any habitat type was comprised of preferred mule deer forage (Table 4), with the exception of preferred grass species, which made up $22 \%$ and $41 \%$ of the ground cover in pinyon-juniper and grassland types, respectively. Almost all of this was blue grama ( $B$. gracilis [H. B. K.] Lag. ex Steud), a warm-season grass that provides only a minor contribution to mule deer diets overall. Ranked abundance of preferred grass species was grassland $>$ pinyon-juniper $>$ montane conifer $\left(H_{2}=28.6 ; P<\right.$ 0.0001). Abundance of preferred shrubs (primarily oakbrush [Quercus spp.]) was pinyon-juniper $=$ montane conifer $>$ grassland $\left(H_{2}=9.9 ; P=0.007\right)$. Habitat types did not differ for preferred forb cover $\left(H_{2}=0.1 ; P=0.937\right)$, and preferred forbs were absent in pinyon-juniper and montane conifer habitats (Table 4).

Home Ranges Versus Landscape. Mule deer home ranges contained more shrub $(U=-9.5 ; P<0.0001)$ and forb $(U=-10.9 ; \quad P=<0.001) \quad$ but less grass $\quad(U=-9.3$; $P<0.0001)$ cover than did the landscape in general (Table 5). For preferred mule deer forages only, mule deer home ranges

Table 3. Differences in proportion of mule deer locations in summer and winter by habitat type relative to percent composition of mule deer home annual ranges. Differences are shown in bold, and selection ratios ( $S R=$ percent of locations/percent composition of deer home ranges, SR $>1=$ use exceeding availability, SR $<1=$ use less than proportional availability) are presented for significant differences.

\begin{tabular}{|c|c|c|c|c|c|}
\hline \multirow[b]{2}{*}{ Habitat } & \multirow[b]{2}{*}{ Annual home range } & \multicolumn{4}{|c|}{ Difference from home range composition (\%) } \\
\hline & & Summer & SR & Winter & SR \\
\hline Barren & 0.64 & -0.14 & - & -0.20 & 0.69 \\
\hline Montane & 21.62 & -8.28 & 0.62 & -5.29 & - \\
\hline Pinyon/juniper & 28.93 & +3.40 & 1.12 & +3.56 & - \\
\hline Shrub & 0.52 & +10.55 & 21.29 & +7.32 & 15.08 \\
\hline Grass & 42.27 & -6.38 & 0.85 & -3.84 & - \\
\hline Developed & 4.79 & +4.06 & - & +3.06 & - \\
\hline Riparian & 1.06 & +0.63 & - & -0.65 & - \\
\hline Free water & 0.15 & +0.01 & - & -0.11 & 0.27 \\
\hline
\end{tabular}


Table 4. Mean (SD) percent cover of total and preferred grasses, forbs, and shrubs on short-grass prairie, pinyon-juniper, and montane conifer sites in north-central New Mexico, 2002-2004. ${ }^{1}$

\begin{tabular}{|c|c|c|c|c|c|c|}
\hline \multirow[b]{2}{*}{ Cover } & \multicolumn{3}{|c|}{ All plants } & \multicolumn{3}{|c|}{ Preferred forage } \\
\hline & Grass & PJ & Con & Grass & PJ & Con \\
\hline Grass & 50 (12)A & $26(13) B$ & $14(8) \mathrm{C}$ & 41 (11)A & $22(12) B$ & $6(8) C$ \\
\hline Shrub & $2(13) C$ & 6 (7)A & $4(4) B$ & $0(0) B$ & $6(7) A$ & $3(4) A$ \\
\hline
\end{tabular}

${ }^{1}$ Grass indicates short-grass land; PJ, pinyon-juniper; Con, montane conifer. Means not sharing an uppercase letter within a row and category (All plants, Preferred forage) differ $(P<0.10)$.

contained more preferred shrub cover $(9 \%$ vs. $3 \% ; U=-6.7$ $P<0.0001)$, but forb $(0.1 \%$ vs. $0.1 \% ; U=0.0 ; P=1.000)$ and grass $(14 \%$ vs. $23 \% ; U=-1.4 ; P=0.154)$ cover did not differ (Table 5).

\section{DISCUSSION}

Body condition of adult does in north-central New Mexico was negatively related to the amount of pinyon-juniper in their home range. Pinyon-juniper communities typically produce little understory vegetation (unless disturbed) for a variety of reasons, including extremely high competitive ability for water, interception of solar energy and precipitation, litter accumulation, phytotoxic root exudates, and binding of nutrients, especially nitrogen, in litter or in the trees (Jameson 1967; Miller et al. 1979; Schott and Pieper 1985; Van Hooser et al. 1993; Dahms and Geils 1997). As a consequence, little forage is generally available in pinyon-juniper communities as canopy cover increases (Van Hooser et al. 1993). We found that forbs and shrubs considered moderate- or better-quality forages for mule deer constituted $0 \%$ and $5.7 \%$ of the total ground cover in pinyon-juniper communities, respectively (Table 4). This lack of preferred forages likely contributed to the strong negative relationship between deer body fat levels and the proportion of pinyon-juniper communities in home ranges. Although other habitat types (i.e., grasslands and montane conifer) also produced little preferred mule deer forage (Table 4), they were either not selected for (montane conifer) or selected against (grasslands) in terms of their proportions in mule deer home ranges versus proportions in the landscape. In contrast, pinyon-juniper communities were present in home ranges from $12 \%$ to $16 \%$ greater than their proportion on the landscape. Because of this strong inclusion of pinyon-juniper in deer home ranges, the effects of limited mule deer forage were stronger than other habitat types.

Pinyon-juniper communities did provide some preferred grass species $(22 \%$ of ground cover), but this was almost exclusively blue grama. Blue grama is a warm-season grass that has a limited period of rapid growth and hence palatability to mule deer in the Southwest (Monsen et al. 2004). In general, studies on desert grasslands and arid pinyon-juniper woodlands have shown that shrubs constitute the vast majority of mule deer diets throughout the year, with grasses and forbs comprising variable amounts but generally $<15 \%$ of the diet (Boeker et al. 1972; Krausman et al. 1997). Likely because of this, doe home ranges in north-central New Mexico contained significantly more preferred browse than did the landscape but not grasses or forbs (Table 5).

Home range sizes generally decrease as habitat quality improves (Robinson and Bolen 1984). In north-central New Mexico, home range size was positively related to the proportion of grasslands in home ranges. This was likely related to the limited cover available for mule deer in grassland types (Severson 1981). Despite the negative relation between body fat and pinyon-juniper, pinyon-juniper was included in home ranges to a greater extent than it was present on the landscape (Table 2), and deer were located in pinyon-juniper communities more frequently than expected based on presence in home ranges (Table 3). Despite the lack of forage, pinyonjuniper communities were likely important to deer for security cover (Lutz et al. 2003). Mule deer are sensitive and vulnerable to both human-related and other disturbance and depend on cover to limit energy losses from having to flee disturbance or from being killed by natural or human predators (Lutz et al. 2003), and pinyon-juniper communities provided this cover. Management strategies aimed at enhancing deer condition thus must improve nutritional attributes of pinyonjuniper communities while maintaining their role as security cover.

Conversely, grasslands provided essentially no cover for adult deer (combined shrub and tree cover $=2.3 \%$; Table 4 ), especially if associated riparian areas have little cover (Severson 1981). Thus, while deer may potentially benefit to some degree from use of grasslands, use of this habitat type is likely limited by the absence of security cover because use of grasslands by

Table 5. Mean (SD) percent cover of grasses, forbs and shrubs, and grasses, forbs, and shrubs that are preferred forages of mule deer, in mule deer home ranges, and the landscape inclusive of habitat type, 2003-2004. ${ }^{1}$

\begin{tabular}{lccccc}
\hline & \multicolumn{3}{c}{ All plants } & & \multicolumn{2}{c}{ Preferred forage } \\
\cline { 2 - 3 } \cline { 5 - 6 } Cover & Landscape & Home range & Landscape & Home range \\
\hline Grass & $30(18) \mathrm{A}$ & $20(10) \mathrm{B}$ & $23(18)$ & $14(8)$ \\
Forb & $1(2) \mathrm{A}$ & $2(3) \mathrm{B}$ & $0.1(0.1)$ & $0.1(0.2)$ \\
Shrub & $4(5) \mathrm{A}$ & $13(7) \mathrm{B}$ & $3(5) \mathrm{A}$ & $9(5) \mathrm{B}$ \\
\hline
\end{tabular}

${ }^{1}$ Means not sharing an uppercase letter within a row and category (All plants, Preferred forage) differ $(P<0.10)$. 
mule deer appears to be more dependent on cover requirements than food (Severson 1981). Even woody windbreaks may not be used by mule deer in grassland habitats if not associated with locally rugged topography (escape topography) (Severson 1981). Moreover, preferred forb and shrub cover was $<1 \%$ in grasslands in north-central New Mexico (Table 4), indicating that grasslands also provide very little forage to mule deer except for blue grama. Consequently, grasslands apparently provide little to mule deer in north-central New Mexico, likely because of both limited food (Table 4) and a lack of cover (Severson 1981).

Montane conifer was the third predominant habitat type in our study area and showed similar vegetation characteristics as pinyon-juniper but with less understory development (Table 4) because of higher overstory stem densities (203 vs. 66 stems $\left.\cdot \mathrm{ha}^{-1}\right)$ and canopy cover $(60 \%$ vs. $25 \%)$. Thinning overstory canopy in montane conifer types has consistently been shown to be the key management strategy to allow development of a diverse and productive understory in the Southwest (Pearson 1968; Reynolds 1969; Clary and Larson 1971; Thill et al. 1983; Dahms and Geils 1997). Mule deer were located in montane conifer less than expected based on its occurrence in home ranges would predict (Table 3), suggesting that lack of forage was limiting use of these areas.

While other habitat types were present only in small quantities in the landscape $(\leq 2.1 \%$; Table 1$)$ and home ranges $(\leq 4.8$; Table 2$)$, mule deer appeared to be strongly attracted to the shrub habitat types of their home ranges. Doe home ranges also contained more preferred browse than did the landscape in general (Table 5). Shrub communities comprised $0.5 \%$ of home ranges on average, yet $>11 \%$ (selection ratio $=21.3$ ) and $>7 \%$ (selection ratio $=15.1$ ) of summer and winter locations were in shrub communities, respectively (Table 3), indicating use of $>1500 \%$ more than availability. Shrub communities, primarily oakbrush and mountain mahogany (Cercocarpus montanus Raf.) in north-central New Mexico, are highly preferred by mule deer for both food and cover (Stevens and Davis 1985; Lutz et al. 2003), and shrubs typically make up $>80 \%$ of mule deer diets in pinyon-juniper and other arid habitats (Boeker et al. 1972; Krausman et al. 1997). Thus, shrub communities were likely important to mule deer, but their limited occurrence (only $0.7 \%$ of the landscape and $0.5 \%$ of mule deer home ranges; Tables 2 and 3) likely precluded identifying any strong relations between deer condition or home range sizes and occurrence of shrub communities. Because mule deer were showing high use of this type, however, maintenance and enhancement of shrub communities in north-central New Mexico should be a management priority.

\section{MANAGEMENT IMPLICATIONS}

Modeling of body fat of mule deer does as a function of home range characteristics indicated that management actions focused on pinyon-juniper can have the greatest effect on deer habitat quality, nutritional condition, and consequently population productivity. Actions should be focused at improving the quantity and quality of mule deer foods while maintaining adequate amounts of security cover for deer. These actions include opening of the canopy in strips or savannahs (Pearson 1968; Reynolds 1969; Clary and Larson 1971; Thill et al. 1983; Van Hooser et al. 1993; Dahms and Geils 1997) but not complete removal unless other habitat features such as deciduous shrubs are present that could similarly serve as security cover. Prescribed burning after canopy removal, in late winter or early spring, could also help increase forage quality by freeing nutrients bound in litter and slash and enhancing protein levels in forage during the late gestation and early lactation period (Dills 1970; Miller et al. 1979; Hobbs and Spowart 1984).

The second-strongest negative habitat association was with grasslands, but here management is more complex than with pinyon-juniper woodlands. The negative attributes of grassland result from both little or no cover and little or no forage other than blue grama. Management thus needs to focus on providing both cover and forage. Prescribed burning on a short interval (3-5 years) can enhance the forb component of short grasslands (Ford and McPherson 1996) but does nothing to enhance cover. Cover could be provided by establishing woody shrub patches near or adjacent to locally rugged topography (Severson 1981), but this is expensive and potentially covers little area. Efforts to establish cover in grasslands may be facilitated by focusing on riparian corridors, especially establishment of deciduous shrub (willow [Salix spp.], sumac [Rhus spp.], and so on) stands throughout the corridor (Severson 1981). These stands provide both cover and browse for deer and allow access to adjacent grassland area. Rehabilitation of these areas is also facilitated by pinyon-juniper management actions upstream from grassland communities, as control of pinyon-juniper may increase water flow to lower portions of streams (Roundy and Vernon 1999).

Further, mule deer were located in shrub communities far more often than their occurrence on the landscape would predict, suggesting that these may be of high value to mule deer despite their lack of relations to deer condition. Moreover, shrub communities in north-central New Mexico are commonly being invaded by pinyon-juniper. Management should act to maintain or enhance these communities, especially where being invaded by pinyon-juniper. Shrub communities, especially oakbrush, are most valuable to mule deer if in early seral stages (Stevens and Davis 1985; Monsen et al. 2004). Management treatments emphasizing late winter or spring burns can be used to keep communities in early successional stages and thus of greatest potential benefit to mule deer (Monsen et al. 2004).

\section{LITERATURE CITED}

Anthony, R. G. 1976. Influence of drought on diets and numbers of desert deer. Journal of Wildlife Management 40:140-144.

Bender, L. C., L. A. Lomas, And J. Browning. 2007. Condition, survival, and causespecific mortality of adult female mule deer in northcentral New Mexico. Journal of Wildlife Management 71(4) (in press).

Boeker, E. L., V. E. Scott, H. G. Reynolds, and B. A. Donaldson. 1972. Seasonal food habits of mule deer in southwestern New Mexico. Journal of Wildlife Management 36:56-63.

Carpenter, L. H. 1998. Deer in the West. In: J. C. deVos, Jr. [ed.]. Proceedings of the 1997 Deer/Elk Workshop Rio Rico, Arizona. Phoenix, AZ: Arizona Game and Fish Department. p 1-10. 
Clary, W. P., and F. R. Larson. 1971. Elk and deer use are related to food sources in Arizona ponderosa pine. Research Note RM-202. Fort Collins, CO: US Forest Service Rocky Mountain Research Station. 4 p.

Clements, C. D., and J. A. Young. 1997. A viewpoint: rangeland health and mule deer habitat. Journal of Range Management 50:129-138.

Cook, R. C. 2000. Studies of body condition and reproductive physiology in Rocky Mountain elk [thesis]. Moscow, ID: University of Idaho. $117 \mathrm{p}$.

Dahms, C. W., AND B. W. Gells. 1997. An assessment of forest ecosystem health in the United States. General Technical Report RM-GTR-295. Fort Collins, CO: US Forest Service, Rocky Mountain Research Station. 97 p.

Dietz, D. R., And J. G. Nagy. 1976. Mule deer nutrition and plant utilization. In: G. W. Workman and J. B. Low [EDs.]. Mule deer decline in the West: a symposium. Logan, UT: Utah State University, College of Natural Resources. p 71-78.

DııLs, G. G. 1970. Effects of prescribed burning on deer browse. Journal of Wildlife Management 34:540-545.

Erron, B., and R. J. Tibshirani. 1993. An introduction to the bootstrap. New York, NY: Chapman and Hall. 436 p.

Ford, P. L., AND G. R. McPherson. 1996. Ecology of fire in shortgrass prairie in the southern Great Plains. In: General Technical Report RM-GTR-285. Fort Collins, CO: US Forest Service, Rocky Mountain Research Station. p 20-39.

GILL, R. B. 2001. Declining mule deer populations in Colorado: reasons and responses. Special Report 77. Denver, C0: Colorado Division of Wildlife. $36 p$.

Heffelfinger, J. R., L. H. Carpenter, L. C. Bender, G. L. Erickson, M. D. Kirchroff, E. R. LOFT, AND W. M. Glasgow. 2003. Ecoregional differences in population dynamics. In: J. C. deVos, Jr., M. R. Conover, and N. E. Headrick [eds.]. Mule deer conservation: issues and management strategies. Logan, UT: Berryman Institute Press. p 63-91.

Heffelfinger, J. R., and T. A. Messmer. 2003. Introduction. In: J. C. deVos, Jr., M. R. Conover, and N. E. Headrick [EDS.]. Mule deer conservation: issues and management strategies. Logan, UT: Berryman Institute Press. p 1-12.

HobBs, N. T., and R. A. Spowart. 1984. Effects of prescribed fire on nutrition of mountain sheep and mule deer during winter and spring. Journal of Wildlife Management 48:551-560.

JAMESON, D. A. 1967. The relationship of tree overstory and herbaceous understory vegetation. Journal of Range Management 20:247-249.

Krausman, P. R., A. J. Kuenzi, R. C. Etchberger, K. R. Rautenstrauch, L. L. Ordway, and J. J. HeRvert. 1997. Diets of desert mule deer. Journal of Range Management $50: 513-522$

Lomas, L. A., And L. C. Bender. 2007. Survival and cause-specific mortality of neonatal mule deer fawns, northcentral New Mexico. Journal of Wildlife Management 71(3) (in press).

Lutz, D. W., B. F. Wakeling, L. H. Carpenter, D. Stroud, M. Cox, D. McWhirter, S. Rosenstock, L. C. Bender, and A. F. Reeve. 2003. Impacts and changes to mule deer habitat. In: J. C. deVos, Jr., M. R. Conover, and N. E. Headrick [EDs.]. Mule deer conservation: issues and management strategies. Logan, UT: Berryman Institute Press. p 13-61.

McClean, S. A., M. A. Rumble, R. M. King, and W. L. Baker. 1998. Evaluation of resource selection methods with different definitions of availability. Journal of Wildlife Management 62:793-801.

Miller, H. G., J. M. Cooper, J. D. Miller, and 0. Pauline. 1979. Nutrient cycles in pine and their adaptation to poor soils. Canadian Journal of Forest Research 9:19-26.

Monsen, S. B., R. Stevens, and N. L. Shaw. 2004. Restoring western ranges and wildlands. Volume 2. General Technical Report RMRS-GTR-136-vol-2.
Fort Collins, C0: US Forest Service, Rocky Mountain Research Station. p 295-698.

Murphy, D. A., and J. A. Coates. 1966. Effects of dietary protein on deer. Transactions of the North American Wildlife and Natural Resources Conference 31:129-138.

Pearson, H. A. 1968. Thinning, clearcutting, and reseeding effect deer and elk use of ponderosa pine forests in Arizona. Research Note RM-119. Fort Colllins, CO: US Forest Service, Rocky Mountain Research Station. 4 p.

REYNoLds, H. G. 1969. Improvement of deer habitat on southwestern forest lands. Journal of Forestry 67:803-805.

Robinette, W. L., O. Julander, J. S. Gashwiler, and J. G. Smith. 1952. Winter mortality of mule deer in Utah relation to range condition. Journal of Wildlife Management 16:289-299.

Robinson, W. L., AND E. B. Bolen. 1984. Wildlife ecology and management. New York, NY: Macmillan Publishing. 478 p.

Roundy, B. A., And J. L. Vernon. 1999. Watershed values and conditions associated with pinyon-juniper communities. In: S. Monsen and R. Stevens [comps.]. Proceedings: ecology and management of pinyon-juniper communities within the interior West. Proceedings RMRS-P-9. Ogden, UT: US Forest Service, Rocky Mountain Research Station. p 172-187.

Schott, M. R., And R. D. Pieper. 1985. Influence of canopy characteristics of oneseed juniper on understory grasses. Journal of Range Management 38: 328-331.

Severson, K. E. 1981. Plains habitats. In: O. C. Wallmo [ed.]. Mule and black-tailed deer of North America. Lincoln, NE: University of Nebraska Press. p 459-486.

Slauson, W. L., B. S. Cade, and J. D. Richards. 1991. User manual for BLOSSOM statistical software. Fort Collins, C0: National Ecology Research Center. $61 \mathrm{p}$.

Stephenson, T. R., V. C. Bleich, B. M. Pierce, and G. P. Mulcahy. 2002. Validation of mule deer body composition using in vivo and post-mortem indices of nutritional condition. Wildlife Society Bulletin 30:557-564.

Stevens, R., AND J. N. Davis. 1985. Opportunities for improving forage production in the Gambel oak types of Utah. In: K. L. Johnson [ED.]. Proceedings of the Third Utah Shrub Ecology Workshop, 30-31 August 1983. Logan, UT: College of Natural Resources, Utah State University. p 37-41.

TABER, R. D. 1953. Studies of black-tailed deer reproduction on three chaparral cover types. California Fish and Game 39:177-186.

Thill, R. E., P. F. Ffollott, and D. R. Patton. 1983. Deer and elk forage production in Arizona mixed conifer forests. Research Paper RM-248. Ft. Collins, C0: United States Forest Service, Rocky Mountain Research Station. $13 p$.

Van Hooser, D. D., R. A. O'Brien, and D. C. Coluins. 1993. New Mexico's forest resources. Resource Bulletin INT-79. Ogden, UT: US Forest Service, Intermountain Research Station. $110 \mathrm{p}$.

Verme, L. J., and D. E. Ullrey. 1984. Physiology and nutrition. In: L. K. Halls [ed.]. White-tailed deer: ecology and management. Harrisburg, PA: Stackpole Books. p 91-118.

WAKeLING, B. F., AND L. C. Bender. 2003. Influence of nutrition on mule deer biology and ecology. In: J. C. deVos, Jr., M. R. Conover, and N. E. Headrick [eDs.]. Mule deer conservation: issues and management strategies. Logan, UT: Berryman Institute Press. p 93-118.

Worton, B. J. 1995. Using Monte Carlo simulation to evaluate kernel-based home range estimators. Journal of Wildlife Management 59:794-800.

Wroming Game And Fish. 1982. Biological techniques. Cheyenne, WY: Wyoming Game and Fish Department. $442 \mathrm{p}$.

ZaR, J. H. 1996. Biostatistical analysis. 3rd ed. Upper Saddle River, NJ: Prentice Hall. $662 p$. 